\title{
Immigration Politics
}

\author{
Jeffrey C. Isaac
}

"You are a Greek Jew? I thought all Greeks were Orthodox?" As a Jewish-American growing up in New York City, whose paternal grandparents were Jews who had emigrated from Greece in the 1920s, I was frequently asked this question by well-meaning-if confused - friends and acquaintances. Indeed, while "Greek Jew" has always been a central aspect of my multiply-hyphenated American identity, in fact my grandfather Morris Isaac, né Izaki, was from Salonika and, it turns out, he himself grew up as a Turkish Jew under the Ottoman Empire, only to discover after World War I that he was in fact (now) not a Turkish but a Greek Jew (which was not, in the parlance of his time, synonymous with being an authentic "Greek"). Greek (Orthodox) or Jewish? Greek or Turkish? Pogroms, wars, "ethnic cleansings," and sometimes even genocides have been undertaken to resolve such questions, and indeed my ancestors experienced all of these things in the opening decades of the twentieth century. For my family, such traumas are part of the story of how my grandparents came to leave Greece and migrate to the US and become Americans and US citizens (alas, many of their relatives were not able to leave, and most ultimately perished at the hands of the Nazis).

Most of the denizens of our world could tell similar stories about the intersection of their family historieswhether recent or remote- and the complex and shifting relationships between religion, ethnicity, nationality, territory, and citizenship that shape the destinies of the concrete human beings who inhabit our world. They are stories of suffering and aspiration, displacement and migration, exclusion and expulsion, inclusion and incorporation, violence and politics, all inextricably linked. The master narratives of modern politics - and the master themes of modern political science-center on state-building and constitution-making and the construction of territoriallybased citizenship. At the same time, the boundaries of states are porous and shifting, and how they contain and exclude populations also changes over time, sometimes in traumatic and incendiary ways. In our own time these complexities are major loci of political conflict and major themes of political analysis. And one of the most ethically challenging and politically compelling sites of this attention is the politics of immigration. Indeed, immigration politics is a major topic of controversy in every part of the world, but especially in the most advanced liberal democ- racies, including the US. And so we have decided to feature this topic in our Book Review section, and to introduce this issue's articles with this important theme in mind.

Throughout Europe democratic states in an expanding European Union are challenged by the incorporation of mobile populations from the East and from the South, from the former Communist world, and especially from the post-colonial world. Particularly in the post $9 / 11$ period, the most visible and politically contentious challenges of inclusion are associated with growing Islamic populations. From French controversies about headscarves, veils, and laïcité to British debates about the validity of Sharia law to broader European arguments about the worthiness of Turkey for European Union membership, the incorporation of Muslim populations has been a lightning rod of political controversy throughout Europe (a topic nicely discussed in Cas Mudde's review of Simon Bornschier's Cleavage Politics and the Populist Right: The New Cultural Conflict in Western Europe and Rafaela M. Dancygier's Immigration and Conflict in Europe, and in Louis DeSipio's review of Marc Morjé Howard's The Politics of Citizenship in Europe and Thomas Janoski's The Ironies of Citizenship: Naturalization and Integration in Industrialized Countries). A particularly vivid and symbolic instance of this was the 2005 Danish cartoon controversy, which raised fundamental questions about multicultural difference and respect, freedom of expression, the "viral" nature of contemporary media politics, and the transnational aspects of cultural and political Islamism. Jytte Klausen's The Cartoons That Shook the World (Yale 2009) offers an important account of this controversy, and our symposium on the book, featuring Donald Downs, Cécile Laborde, Anne Norton, Abdulkader Sinno, and Carolyn $\mathrm{M}$. Warner, presents a wide range of political science perspectives on the issues it raises and their centrality to the contemporary politics of liberal democracy.

Similar challenges face the US, defined since its inception by diverse waves of immigration, narratives of ethnic "melting pots" and rhetoric of "e pluribus unum." Fundamental aspects of American political identity and state structure have recently been put to the test by the politicization of the US encounter with Mexico, Mexicans, and especially those millions of people from Mexico who have migrated to the US in search of opportunity, who have established residence, become full participants in society, 
had children and raised families, and yet nonetheless enjoy the precarious status of "undocumented workers," "illegal aliens," and foreigners. In recent months the state of Arizona has been a veritable ground zero of immigration politics at its most bitter and contentious, though as I write in June of 2011, a harsh new law just passed by the Alabama state legislature has caused a leader in the movement for immigration restriction to declare that "Alabama is the new No. 1 state for immigration enforcement."

This issue's "Reflections" essays by Elizabeth F. Cohen and Rogers M. Smith directly engage these ongoing political controversies. Cohen's "Reconsidering US Immigration Reform: The Temporal Principle of Citizenship," surveys main lines of contention in current US debates about immigration reform and advocates a pragmatic approach to questions of reform that centers on the question of how long immigrants have resided in the country. Cohen argues that this approach can be traced to the nation's founding period, whose "case law and legislative history ... clearly demonstrate an original intent to provide a path to citizenship even for foreign-born persons with highly irregular political status," and that "moving beyond interpretations of the Fourteenth Amendment opens up fertile new terrain for discussions about how policies can be crafted to accommodate the reality of perpetually porous borders and a labor market that has absorbed millions of unauthorized immigrants."

Rogers M. Smith's "Living in a Promiseland? Mexican Immigration and American Obligations" similarly integrates political and constitutional theory and policy analysis to defend a politically pragmatic approach to immigration reform. Smith argues that "history provides grounds for recognizing that the US government has special obligations to Mexicans and Mexican Americans as a result of the ways it has coercively constituted their identities, values, and aspirations," but at the same time "the US also has special obligations to other members of its states, local governments, and citizenry." He proceeds to sketch out some of the complex policy implications of this general approach, from forms of dual cultural, economic, and political nationality to raising the national ceiling for legal immigrants from Mexico to laws, such as the DREAM Act, that extend opportunities for citizenship to undocumented young people who commit to military service or post-secondary education. Like Cohen, Smith is less interested in defending specific proposals than he is in outlining compelling and reasonably inclusive values and principles on the basis of which policies can be negotiated. As he writes, "I seek to take into account the interests and aspirations represented by American state and local governments who are recipients of Mexican immigration, particularly Arizona; the interests and aspirations represented by the Mexican national government; and the interests and aspirations of Mexicans, Mexican Americans, and Americans more generally." Given the timeli- ness of Smith's argument, it seemed appropriate to invite responses from a range of prominent political scientists working on the politics of Mexican immigration. Rafael Alarcón, Edwina Barvosa, and Louis DeSipio each raise serious questions about the extent to which Smith, by calling for new terms of negotiation among a range of US and Mexican stakeholders, reaches so broadly as to be politically naïve about the forces supporting stronger borders and tighter restrictions. The dialogue between Smith and his interlocutors is a model of serious and sharp scholarly debate on matters of pressing contemporary relevance, and also a model of how empirical and normative analyses can fruitfully be combined.

One key bone of contention in current debates about immigration reform in the US context is the question of "birthright citizenship" and its meaning, and whether, as the Fourteenth Amendment to the US Constitution states, "All persons born or naturalized in the United States, and subject to the jurisdiction thereof, are citizens of the United States and of the State wherein they reside." In different ways, both Cohen and Smith seek to move the debate away from such strictly legalistic argumentswhether advanced by proponents of more or less restrictive immigration policies - in the direction of a more sensitive, publicly legitimate, and inclusive immigration policy. While both argue that the question of "birthright" is not a sufficient criterion for a sound immigration policy, Ayelet Shachar's The Birthright Lottery levels a more fundamental attack on the very value of "birthright" as a moral category. According to Shachar, the question of where one is born is as morally irrelevant as the question of from whom one is born, and it is unjust for these contingent facts to powerfully shape the lifechances of individuals. For Shachar, it makes no moral sense that a child born in San Diego, California and another born a few feet away in Tijuana, Mexico, should have dramatically unequal access to the rights and opportunities associated with citizenship due to this accident of geography. And yet in a world of sovereign nationstates, fundamental rights and opportunities are assigned by just such a lottery of birth. In our symposium on Shachar's provocative book, Linda Bosniak, John EcheverriGent, Terri E. Givens, and Jane Junn assess the moral and political implications of Shachar's critique of birthright citizenship, with particular attention to current US debates about immigration and the ethical and pragmatic value of the Fourteenth Amendment.

The question of who gets to be included in the United States - who gets to be, to live, and to work here, and who gets to fully "count" here-is linked to an even larger question: what is the United States, a state like any other, or a state that is in some sense "exceptional" in either its structure or its ideological pretensions, or both? This question has been central to much recent work on American political development, and it lies at the heart of our lead 
article, Desmond King and Marc Stears' "How the U.S. State Works: A Theory of Standardization." King and Stears proceed from the fact that the US has often be treated, especially by American scholars of US politics, as a unique polity whose possession of conventional (European) characteristics of "stateness" is in doubt. At the same time, they resist this tendency, preferring instead to treat the US, comparatively, as a state characterized by a dynamic of standardization. As they write:

Despite an extensive rhetoric of plurality and individualism, the history of American state-building has been punctuated with periods of intense government activity to "standardize" citizens and potential citizens. Wartime Americanization drives, such as those in the 1910s, are a prominent instance of using assimilation to standardize: advocates set out English language requirements and in early-twentieth-century versions rejected the cultural plurality of diverse immigrants' ethnic background, urging that they embrace a common standard of identity and patriotism. But this punitive use of standardization-versions of which recurred during the Second World War, during the Cold War years notably under the McCarthy anti-communist hearings, and after the 9/11 terrorist attacks — has been joined by a more positive version of American government standardization efforts.

In short, the US state has perennially been at the center of political conflict and public policy formation-since the Civil War and indeed since the "founding" of the American republic in 1787-in its capacity as a means of violence, administration, and legality, and of repression as well as empowerment.

At the same time, one of the distinctive though hardly unique characteristics of the US state is its federal character, which is inscribed in the constitutional status of the US Senate and the Electoral College, but most importantly in the US Constitution's division of powers between the national and state governments. As Rogers Smith's essay makes clear, federalism has played a crucial role in current US political battles over immigration. It has played an even more important role in the US politics of education, which has long been shaped by state and local financing and by an ethos of "local control." Indeed, only in 1980 was the US Department of Education established as a cabinet-level agency of the federal government-a status that remains hotly contested. At the same time, public education has long been a central ingredient in the American democratic creed, and public schools have played an essential role in the narrative of the US as a "civic nation" and a "melting pot."

Jesse Hessler Rhodes's "Progressive Policy Making in a Conservative Age? Civil Rights and the Politics of Federal Education Standards, Testing, and Accountability" sheds important light on the complex meanings, functions, and political dynamics that shape public education in the US. Hessler offers careful case studies of the origins of three of the most important recent federal standards, testing, and accountability laws: the Improving America's Schools Act of 1994; the No Child Left Behind Act of 2002; and the
Race to the Top initiative of 2009-2010. While these laws have often been seen as the outcomes of conservative mobilization, Hessler argues that the key impetus to these reforms came from civil rights organizations, which saw them as means of enhancing the academic opportunities of disadvantaged youth. Consistent with King and Stears, Hessler interprets this relatively recent federal "standardization" of education as a function of a broader politics centered on the development of the American state. At the same time, like King and Stears, Hessler points out that the consequences of such developments are often neither intended nor benign. He thus concludes that "progressive groups may find achieving legislative victories easier than accomplishing substantive objectives; and that winning reforms may unleash complex and unpredictable political consequences. There has been considerable policy change ... but fundamental transformations that move education in a more egalitarian direction remain elusive." Joseph P. Viteritti offers a similar prognosis in his terrific review essay, "Whose Equality?: The Discouraging Politics of American Education (and What We Might Do about It)." Viteritti covers much of the same ground as Rhodes. Offering a careful overview of recent scholarship on educational achievement and educational policy, Viteritti also offers a tour de force critique of the democratic failings of the US system of education, in which ideological dogmatism, federalism, and class combine to reproduce a system that is both inefficient and inegalitarian.

Viteritti opens his piece by calling attention to the Report of the 2004 American Political Science Association Task Force on Inequality and American Democracy, and he closes it by urging political scientists to "not forget who we are and what we have to offer to this pressing set of challenges." In making this appeal, Viteritti offers a wonderful segue to our symposium on a book written by two members of the 2004 APSA Task Force, Jacob S. Hacker and Paul Pierson's Winner-Take-All Politics: How Washington Made the Richer Richer-And Turned Its Back on the Middle Class. As I observed in my editorial charge to the Symposium participants, this book is important as a work of empirical political science and as a contribution to broad public discussion of distributive politics. From our vantage point it is also important because its critique of the subfield of "American politics" for its focus on the voterpolitician linkage and on "politics as spectacle" rather than "politics as organized combat" raises broad questions about how American political science can best move forward in its effort to address the social, economic and political challenges of the twent-first century. In our symposium on the book-the largest book symposium we have thus far run-a wide range of political scientists, some "Americanists" and some not, address these questions, and in so doing they enact one of the core values of this journalthe value of ongoing dialogue and critical and constructive scholarly debate about matters of consequence. 


\section{Statement of Mission and Procedures}

Perspectives on Politics seeks to provide a space for broad and synthetic discussion within the political science profession and between the profession and the broader scholarly and reading publics. Such discussion necessarily draws on and contributes to the scholarship published in the more specialized journals that dominate our discipline. At the same time, Perspectives seeks to promote a complementary form of broad public discussion and synergistic understanding within the profession that is essential to advancing scholarship and promoting academic community.

Perspectives seeks to nurture a political science public sphere, publicizing important scholarly topics, ideas, and innovations, linking scholarly authors and readers, and promoting broad reflexive discussion among political scientists about the work that we do and why this work matters.

Perspectives publishes work in a number of formats that mirror the ways that political scientists actually write:

Research articles: As a top-tier journal of political science, Perspectives accepts scholarly research article submissions and publishes the very best submissions that make it through our double-blind system of peer review and revision. The only thing that differentiates Perspectives research articles from other peer-reviewed articles at top journals is that we focus our attention only on work that in some way bridges subfield and methodological divides, and tries to address a broad readership of political scientists about matters of consequence. This typically means that the excellent articles we publish have been extensively revised in sustained dialogue with the editor-me- to address not simply questions of scholarship but questions of intellectual breadth and readability.

"Reflections" are more reflexive, provocative, or programmatic essays that address important political science questions in interesting ways but are not necessarily as systematic and focused as research articles. These essays often originate as research article submissions, though sometimes they derive from proposals developed in consultation with the editor in chief. Unlike research articles, these essays are not evaluated according to a strict, doubleblind peer review process. But they are typically vetted informally with editorial board members or other colleagues, and they are always subjected to critical assessment and careful line-editing by the editor and editorial staff.

Scholarly symposia, critical book dialogues, book review essays, and conventional book reviews are developed and commissioned by the editor in chief, based on authorial queries and ideas, editorial board suggestions, and staff conversations.

Everything published in Perspectives is carefully vetted and edited. Given our distinctive mission, we work hard to use our range of formats to organize interesting conversations about important issues and events, and to call attention to certain broad themes beyond our profession's normal subfield categories.

For further details on writing formats and submission guidelines, see our website at http://www.apsanet.org/ perspectives/ 